\title{
The Ethio-Eritrean Post-War Stalemate: An Assessment on the Causes and Prospects
}

\author{
Kidanu Atinafu ${ }^{1}$, Endalcachew Bayeh ${ }^{2}$ \\ ${ }^{1}$ Department of Civic and Ethical Studies, College of Social Sciences and Humanities, Arba Minch University, Arba Minch, Ethiopia \\ ${ }^{2}$ Department of Civic and Ethical Studies, College of Social Sciences and Humanities, Ambo University, Ambo, Ethiopia
}

Email address:

kidanuatinafu@yahoo.com (K. Atinafu), endbayeh@gmail.com (E. Bayeh)

\section{To cite this article:}

Kidanu Atinafu, Endalcachew Bayeh. The Ethio-Eritrean Post-War Stalemate: An Assessment on the Causes and Prospects. Humanities and Social Sciences. Vol. 3, No. 2, 2015, pp. 96-101. doi: 10.11648/j.hss.20150302.15

\begin{abstract}
The people of Eritrea declared their formal independence from Ethiopia after majority of its populations voted in favor of separation in the 1993 referendum. Since the secession, governments of the two countries forged cordial relations and concluded different agreements to regulate their bilateral relations. However, the alliances formed and agreements signed were far from promising and short lived. The various divergences observed in socio-economic and political fields bedeviled their relations which later led for an all-out war of the 1998-2000. Though the war was ended with signing of the Algiers Agreement in 2000 , the relations between the two countries for the last fourteen years remained hostile and at the core of the two countries' hostility is border issue that moved the two countries into different infringes. This piece of paper attempts to uncover the factors accompanying the Ethio-Eritrean post-war impasses and the future prospects.
\end{abstract}

Keywords: Stalemate, War, Destabilization, Peace, Normalization

\section{Introduction: Background Notes on the Historical Relationships of the Two Countries}

Ethiopia and Eritrea have longstanding relations. Peoples of the two countries are not only bounded by common mythology, legend and history but also by blood and ancestral roots. Certain commonalities and complementarities in terms of culture, way of life, language, and religion persisted so far. However, colonial rule that snapped Eritrea from Ethiopia disrupted the intimate relationship of peoples of the two countries. The longstanding political entrapment of Eritrea by foreign powers sowed the seeds of present-day Eritrean nationalism (Lobban, 1976) and modern nationalists portrayed the propaganda of identity difference between the two peoples (Ahmar, 1984). However, it is erroneous to wholly attribute the quest for Eritrean secession to colonial rule that only hastened the consciousness of Eritreans in this direction. The occurrences and the uncompromising stances that took place under both the monarchical and military regimes of Ethiopia also played a lot in this regard. The abrogation of the 1952 federation moved Eritreans to start the guerrilla movements in the direction of separation. And the struggle also intensified following the establishment of the Eritrean People's Liberation Front (EPLF) in the early 1970s. Instead of allowing political concession with the Eritrean nationalists, the Military Regime (Derg) also opted to forcefully conquer and incorporate Eritrea under its rule thereby escalating the struggle with great vigor. Through the joint efforts of EPLF and Tigrean People's Liberation Front (TPLF), the Military Regime had been overthrown in 1991 and the people of Eritrea proclaimed their de facto independence (in 1991) and de jure (in 1993 after the holding of the referendum).

The two countries had established formal state-to-state relations following the 1993 referendum and different agreements were concluded to regulate their bilateral relations (Tekeste and Tronvoll, 2000). These protocols encompass defense pact, harmonization of economic and trade policies, and all public affairs including tourism, education, and health care services (Ibid). Though Ethiopia and Eritrea were in agreement to harmonize the different aspects of their relations including the economy, very little progress was made on the implementation of the protocols (Ibid). Thus, the outcomes of all the agreements and relations did not last long due to various reasons.

According to Tekeste and Tronvoll (2000), lack of political 
willingness and inability to act in the best interests of each other were the hindering factors that dragged back the implementation of the agreements and harmonization of relations. The bilateral relations were short lived due to the fact that the agreements signed and relations formed between the two countries were not well institutionalized and the willingness to act accordingly was non-existent (Bereketeab, 2010). Adequate and effective mechanisms to implement and operationalize the agreements were absent. Acknowledging the relatively peaceful relations between the two countries prior the outbreak of the 1998-2000 war, scholars and commentators also attribute the fragility of the Ethio-Eritrean relations to the deeper ideological differences and animosity that the two liberation fronts (TPLF and EPLF) harbored 1 (Tekeste and Tronvoll, 2000; Medhane, 1999). Some others also attribute the collapse of the Ethio-Eritrean relations due to the failures of the TPLF dominated government of Ethiopia of allowing Eritrea to secede without conducting series negotiations with regard to border demarcation, the issue of currency, the division of assets or liabilities and even as regards the modalities of economic cooperation (see Medhane, 1999). Most importantly, the two governments did not negotiate on the measures to be taken after Eritrea adopted its own currency (Tekeste and Tronvoll, 2000), which resulted in the devastating bloodshed and prevailing disparity.

The 1998-2000 two years war between Ethiopia and Eritrean was caused by complex but interrelated factors (Bereketeab, 2010) and understanding the real cause of the war has become the subject of much debate and writings on the part of academicians, diplomats and politicians. Consensus was not reached on the exact cause of the war (Dima, 2006). Some attribute this to the longstanding political tensions that the two liberation fronts harbored while others attached the issue to economic factors including the introduction of Nakfa- Eritrean currency. Conflicting parties, on the other hand, considered border as the apparent issue of contention (Leenco, 2006). The Eritrean State Building Project was also put an immense impact for the outbreak of the war as Berhane (2006) and Gerbu (2006) argued. The other important factor which accompanied the deterioration of the bilateral relations related with psycho-social issues. According to Medhane (1999), the liberation fronts in Eritrea had a patronized attitude toward the Tigrean movements whereas Tekeste and Tronvoll (2000) stated that EPLF portrayed itself as a senior and dominant front in the region since it predated the establishment of the TPLF. Such feeling of superiority and seniority was coupled with prejudice and seemed to have shaped the position of the two regimes against each other thereby exacerbating the dissonance in their relations in the post-1991 years.

The war was devastating to both countries that can be expressed in terms of human and economic costs. The war cost the lives of hundreds of thousands of peoples from both

1 For further information on how the TPLF and EPLF diverges during the armed struggle against Derg, see (Young, 1996, 1997) sides and millions of dollars were also expended for the procurement and acquisition of sophisticated weapons (ICG, 2003). Though the protracted and bloody fight between the two countries culminated with the signing of the 'Algiers Agreement'2, harmonization or normalization of the EthioEritrean relations remains unfulfilled and the feeling of animosity and suspicion is very potent. Hence, the thematic focus of this paper is to shed light on the underlying causes of the post-war Ethio-Eritrean disparity and the subsequent outcomes including the future prospects.

\section{Factors Underpinning the Ethio- Eritrea Post-War Stalemate}

As a result of the inability of the two countries to reach agreement on the implementation of the decision of the Ethiopia-Eritrea Boundary Commission (EEBC), resolution of border disputes in particular and normalization of their bilateral relations in general has stalled over the last decade. The researchers have identified the following factors (both actual and potential) that spur the stalemate or impasse in the post-Algiers period.

\subsection{Unresolved Border Issues}

As a result of the uncompromising stance and the relative intransigencies of both sides, border issues remain stalled. The willingness on the part of the conflicting parties to reopen discussion on how the actual border demarcation could take place or on the implementation of the decisions of the EEBC with no precondition is still unobservable. The two sides seem to be not willing to moderate their positions so far to end the border deadlocks. Hence, the unresolved border issues are at the heart of the existing stalemate.

The importance of Badme on which the two sides fought has left arduous consequence in entrenching the prevailing impasse. From Ethiopia's side, the government failed to abide by the ruling of the EEBC because doing so would amount to ignore the memory of the troops who gave their life to regain Badme (Leenco, 2006). The Ethiopian government also spent huge amounts of finance in the war. Strong resistance and criticism from domestic stakeholders came to challenge the Ethiopian government urging it not to cede Badme to Eritrea. Not only the politicians but also members of the Badme and Irob communities at large vowed not to give a piece of territory to Eritrea and stood against the decision of the Commission (Solomon, 2004). In the light of this, it will not be easy for the Ethiopian government to give Badme to Eritrea despite the binding nature of the decision of the Commission. From the Eritrean side, conceding Badme is

2Witnessed by the UN Secretary General, the OAU, the European Union and the U.S. the conflicting parties concluded the Algiers Peace Agreement on 12 December 2000 the agenda of which was to end the conflict and bring lasting peace. The conflicting parties agreed to resolve border problems through an independent body whose decision is final and binding. Pursuant to the agreement, the Ethiopia-Eritrea Boundary Commission (EEBC) was established and started its work on 25 May 2001. 
highly unlikely due to two reasons: their troops shed blood in order to gain Badme and a neutral Boundary Commission awarded the area to them (Leenco, 2006). Therefore, Badme becomes a highly symbolic spot for national prestige on both sides and a major source of the Ethio-Eritrean disparity (Abbink, 2003b).

The inadequate conflict resolution strategy employed by the international community also left another repercussion for the stalemate (Dima, 2005; Getachew, 2006). The agreement mandated the EEBC to delimit and demarcate the border based on pertinent colonial treaties (1900, 1902 and 1908) and applicable international law (see Article 4 of the Algiers Agreement). However, the colonial rulers interpreted the border unilaterally and drew new borderlines, which was subjected to frequent changes leaving them un-demarcated as a result of toponymic confusion, misunderstanding among parties as well as incomplete knowledge of the geography of the localities (Ciampi, 2001). Though not mandated by the agreement, the EEBC decided borders without consulting local peoples and based on the decision, the flash pointBadme- was awarded to Eritrea. However, As Abbink (2003b) contends the colonial ruler- Italy- and an independent stateEritrea- never had any exercise of administration or control over Badme and beyond since this had long been administrated by Ethiopia. Hence, the peace process that neglects the voice of local populations and fluidity of border changes did much harm than good (Kalewongel, 2008).

Not only the flawed conflict resolution strategy employed but also the failures of the international community to influence the two countries to come to terms also impacted on the prevailing situation. It is argued that instead of influencing Ethiopia to accept the ruling and collaborate with the Commission during the demarcation process, the international community particularly the US, was suspected of favoring Ethiopia thereby blocking the operationalization of the Commission's ruling (Bereketeab, 2010). The Eritrean leadership was thus annoyed and became too suspicious about the importance of various institutions like UN or AU. Due to the limited influence of the international community, the promises of Algiers Agreement remained on paper thereby perpetuating the existing no-war no-peace situation (Getachew, 2006; Bereketeab, 2010).

\subsection{The Politics of Mutual Intervention and Proxy War}

Destabilization and mutual intervention largely remained the characterizing features of the situation in the Horn of Africa. For instance, prior to the downfall of the military regime, Ethiopia supported the Sudan People's Liberation Army while the Sudanese government established a strong link with the Eritrean Liberation Front-ELF and later EPLF in their fight against the Ethiopian government (Abbink, 2003a). Similarly, the Siyad Barre regime of Somalia extended support to the Western Somali Liberation Front in the Ogaden area of Ethiopia while Ethiopia, in return, assisted northern Somalis in what is now Somaliland against the Siyad regime. Sudan and Eritrea were also engaged in destabilizing each other by supporting the Eritrean Islamic
Jihad and the Sudanese opposition National Democratic Alliance respectively.

Though the Algiers Agreement brought an end to the devastating effects of the war, consensus was not reached on the demarcation of borders and normalization of the relations between Ethiopia and Eritrea. The ruling of the EEBC had not been implemented as a result of which disagreement about the border remains intact. The unresolved nature of the border disputes led to the escalation of destabilization and proxy engagement. The Ethiopian government accused Eritrea of extending support to different insurgents notably the Oromo and Somali ethno-nationalist groups while Eritrea blamed the Ethiopian regime as well (Tekeste and Tronvoll, 2000; Bereketeab, 2010). During the crisis in the aftermath of the 2005 Elections, the government of Ethiopia blamed Eritreans of having a hand in the turmoil (ICG, 2005) and in response Ethiopia also assisted the Eritrean Democratic Alliance and other smaller groups, such as the Red Sea Afar Democratic Organization in their fight against the Eritrean regime (Abbink, 2003a; Kidane, 2011; Bereketeab, 2010).

The consequence of the act of destabilization is pivotal in exacerbating hostility and perpetuating the impasse. This created deeper antipathy and irreconcilability between the two regimes. Each of the parties to the conflict maintained that peace will not prevail unless the other is annihilated. In the light of this, the ex-Ethiopian Prime Minister, Meles Zenawi, repeatedly highlighted that peace in the Horn is "impossible with the present government in Eritrea in place"(Abbink, 2003a: 417) and stated that the Eritrean government is the enemy of both the Eritreans and Ethiopians as well (Tekeste and Tronvoll, 2000). In response, the government of Eritrea never hesitated from emphatically stating that rapprochement with the present Ethiopian government is unthinkable under any circumstances (Abbink, 2003a). The very purpose of both governments is, therefore, to destabilize each other with their extended support to respective opposition groups. Considering the severity of the act of destabilization, Tekeste and Tronvoll (2000) argued that durable peace in Ethio-Eritrean relations will not prevail as far the politics of destabilization is concerned. It is difficult to curtail the impasse and normalize the relations between the two under these circumstances.

The two countries not only delved into destabilizing each other but also the Horn at large. Instead of breaking the stalemate, both countries have been sending troops to neighbouring Somalia in what appears to be a proxy war. The Ethiopia-backed Transitional Government of Somalia to fight the Islamist and terrorist groups by obtaining support from Ethiopia whereas the Eritrean government supported the Islamist groups and other anti-Ethiopian forces that sprung inside Somalia (Kidist, 2011; Kidane, 2011), which was viewed as a security threat by Ethiopia given their irredentist rhetoric and radicalization agenda. The Ethio-Eritrean engagement in the Somalia crisis marked the unresolved nature of the war. In this connection, it is stated that the Eritrean engagement in proxy war with Ethiopia is intended to force Ethiopia to accept the EEBC decision (ICG, 2010). 


\subsection{Unfolding Authoritarianism}

As Abbink (2003a) contends, transition to democracy in Ethiopia and Eritrea is slowed down to varying degrees. The regime in Eritrea failed to open-up the political space for the public to engage freely in the political affairs of the country (ICG, 2010). The post-war stalemate provided justifications for Eritrean leaders to suspend the implementation of the 1997 draft constitution by opening up the space for democratization (Kidist, 2011; Berhane, 2006; Healy, 2007). Preoccupied with the threat coming from intellectuals and other senior liberation war veterans, the regime suspended democracy and election in Eritrea (ICG, 2010) as a result of which the power of the President was consolidated with great vigor through intimidating or arresting opposition groups (Abbink, 2003a; Kidist, 2011; Healy, 2007). Open public debates and political pluralism thus rarely flourished in Eritrea (Healy, 2007).

According to Ogbazghi (2011), the current political space of Eritrea best portrayed a sort of "Personal Rule" whereby the state and its apparatus formed a cult of personality of the incumbent strongman. Berouk concurs with Ogbazghi stating that the post-1991 Eritrean economic and political life was "hijacked" by a single individual and the issue of transparent and accountable governance system was voided. Willingness from the regime to modify authoritarianism became unlikely and all aspects of the administration were controlled by the sole political organization- PFDJ (Ibid). The military with its hierarchy of regional military commanders is under the direct control and leadership of the President too. The relationship between the state and civil society was characterized by a sort of personal tyranny rendering civil society organizations not to engage in any form of policy activism or advocacy matters. The government was too suspicious about the existence of privately owned media (Healy, 2007). Hence, nowadays, only government owned media operated in the country and the government intervenes at any time to deter the dissemination of "unnecessary material" to the public (ICG, 2010).

Compared to its Eritrean counterpart, the regime in Ethiopia is not overtly dictatorial (Gilkes, 1999). As most scholars assert, commitment to establish a mature democracy is still not observed and a stable institutional political structure that will survive the current regime has not yet been put in place (Abbink, 2003a). Though the Ethiopian People's Revolutionary Democratic Front -EPRDF-government conducted different rounds of elections, the legitimacy of the election processes still remains a highly contested issue (Kassahun, 2010). This is mainly due to the fact that the state apparatus, which manages the election process, lacks credibility and neutrality in providing level playing field to all the stakeholders (Kassahun, 2010; Merera, 2007). Incentives for competitive politics and legitimate electoral process under a multi-party framework and policy choices thus remain minimal (Kassahun, 2010) and the freedom of opposition political parties to operate have been circumscribed (Merera, 2007; Wondwosen, 2009). Following the 2005 election crisis, the government intimidated and arrested opposition leaders and their supporters (Wondwosen, 2009). Currently, power is monopolized by a single party. With regard to the independence of media, state repression against the private media increased dramatically (Kassahun, 2010). Consequently, press freedom and civil society organizations working in different socio-economic and political fields are being manipulated.

The forgoing discussion, thus, indicates that the ruling regimes in both countries rely on military power to restrict civil liberties and retain dominance. Following the Algiers Agreement, both regimes responded to political challenges by repressing dissent and restricting political space (Getachew, 2006) and normalization of relations between the two countries remained the exclusive agenda of the politicians entirely (Bahru, 2006). Opportunities for civil societies and the public to take the initiative in breaking the impasse are not yet observed since they are continuously inhibited (Ibid). Getachew (2006: 68) further contends that maintenance of durable peace between Ethiopia and Eritrea is challenging "without democratizing both societies and tabling a realistic agenda that considers the economic and security interests and the historical realities of both entities." With absence of a democratic and accountable government, where the voices of the mass are neglected, it is difficult to break the no-war no-peace situation and normalize relations between the two countries.

\subsection{The Ethos of Militarism in Eritrea}

The regime in post-war Eritrea is suspicious of its neighbours and the wider world at large. Based on two rationales, the Eritrea government maintained that the international community always acts to the detrimental of Eritrean interests: by suppressing the quest of Eritreans for independence after the end of colonial rule, which is accompanied by the unimplemented nature of the Algiers promises (ICG, 2010). The government also considered neighbouring countries as enemies of Eritrea. Not only the neighbouring states, the government does not trust even its population as a result of which the International Crisis Group in its 2010 Report labeled Eritrea as "siege state" where the government is suspicious of everything.

As a result of its siege mentality, the Eritrean government built a militaristic social system and militarized politics, which spilled into its foreign policy whereby around 10 percent of the Eritrean population has been tied up in military service (Healy and Plaut, 2007) and the defense expenditure constitutes roughly 9 percent of the Gross Domestic Product (ICG, 2005). Since the cessation of the military hostility with Ethiopia, thousands of forces have graduated from the 'Sawa National Service' camp and the majority of the youth are employed in the army (Berhane, 2006; Healy, 2007). Massive remobilization of demobilized fighters and National Military Service conscripts increased drastically (Healy, 2007). Increasing air force training flights and other new trenches along key defensive positions remains intact (ICG, 2005) and now Eritrea has become one of the militarized nations in 
Africa (ICG, 2010).

Therefore, militarism and authoritarianism best define the political environs of the Eritrean government nowadays. Rather than using conventional diplomacy, the Eritrean government resorts to military adventurism in the form of proxy war to force the Ethiopia government to accept the ruling of the EEBC. The government is still behaving like a guerrilla movement with absolute power of life and death over its constituents, and its foreign policy was often conducted aggressively, albeit naively (Ibid). Whereas aggression is used as a preferred means to defend any perceived threat to its sovereignty the behavior of the Eritrean government not only affects its internal development but also its relations with all its neighbours (Healy, 2007). The militarized policy of Eritrea forced the Ethiopian government to be suspicious and less cooperative. In order to offset the threat coming from militaristic Eritrea, the Ethiopian government is also deeply involved in cultivating its combat forces so far. The two countries continued to rearm through buying aircraft, armoured vehicles and artillery from Eastern European suppliers (Plaut, 2005/2006) and heavy deployments of forces along the common borders still remains intact (Solomon, 2004).

The two governments holding power in Ethiopia and Eritrea are battle- hardened and, hence, the ethos of militarism is deep-rooted and highly potent in their day to day activities. Their engagement in proxy warfare and destabilization activities best defines the culture of militarism It is the culture of militarism that disrupts the stability of the region. The thinking here is that, unless the culture of militarism is replaced by new political and diplomatic proficiency, peace will not prevail in the region and the stalemate will persist unabated in the years to come. In this regard, Bahru (2006: 23) rightly stated that:

If there is one thing that the two countries and their peoples should learn from history, it is the fact that recourse to arms has not solved any of the outstanding problems.......... There is in short no alternative to sober discussion and dialogue in order to achieve the peace and development that the two countries so desperately need.

\subsection{Prospects on the Ethio-Eritrean Relations}

The important point to be highlight under this heading is that the prevailing Ethio-Eritrean disparity seems to continue in the years to come. The government to government distrust and denunciation is very powerful and accusation of each other of backing the insurgents to destabilize the other is also the common occurrences witnessed today. As the saying goes 'the enemy of my enemy is my friend', both sides continue to undermine each other's stability through aligning with the various dissident groups and even waging a proxy war in neighbouring countries. The possibility of normalization of the bilateral relations would be a mirage with the presence of such a wicked conduct. As discussed above, the unfolding of the current hostility is due to border discord too. Viable opportunities from the part of the conflicting parties to conduct bilateral discussions on how border problems be resolved and subsequent normalization process would take place are still unobservable despite the 2013 speech made by the Ethiopian Prime Minister, Hailemariam Desalegn, on Aljazeera. 3 Governments of both countries take irreconcilable positions with regard to the resolutions of border problems in particular and other divergences in general. The Eritrean government, in this regard, repeatedly demanded the unconditional implementation of the decisions of the EEBC. And in recent AU summit, Eritrean delegate at AU presented an agenda that request the organization to force Ethiopia to evacuate its force from those areas that the EEBC awarded to it and delimit the common borders based on the binding rulings of the commission. The Ethiopia government, on the contrary, contends that bilateral negotiation is mandatory before the decision of the commission put into effect. Eritrea's demand for unconditional delimitation of the border based on the decision of commission had been annulled and AU appreciated and duly welcomed Ethiopia position of bilateral talk before the conduct of the actual delimitation of the borders. Unless governments of both countries moderate such intransigency and uncompromising stance, the prevailing hostile relations are to be prolonged for undefined periods of time.

\section{Conclusion}

The post-war Ethio-Eritrean strained relations were accompanied by; the unresolved nature of the borders which was the underlying factor for the two years war as the conflicting parties maintained. Though the two countries agreed to resolve border problems through an independent arbitrator, whose decision is binding, the two countries failed to agree on the final decisions of the commission and hence the border discords continued unabated which later worsened the relations. The unresolved nature of the border issues moved the two governments to engage and provoke destabilization and proxy wars as means of influencing the position of one another. Such behaviors and denunciation finally perpetuated the animosity and the mistrust to be deep rooted. Opening up the space for democratic transition where the power of the elite is limited, the voice of the public heard and the rights of civil societies and opposition political parties guaranteed is at the infancy stage (particularly in Ethiopia) and non-existence (true for Eritrea). This political condition of the two countries devoid the public including different civil-political organizations from taking part in the process of bring lasting peace. Due to lack of political transition, the issue of normalization of the Ethio-Eritrean relations is to be limited to the will of key political figures only thereby perpetuating the prevailing no-war no-peace

\footnotetext{
3 The Ethiopian Prime Minister, Hailemariam Desalegn, pronounced that he is willing to hold talks with neighbouring Eritrea to normalize the bilateral relations. The prime minister also acknowledged that his predecessor, Meles Zenawi, had asked for more than 50 times even to go to Asmara and negotiate with Mister Isaias Afwerki,"(for more details see http://www.aljazeera.com/news/africa/2012/12/2012125145129652231.html)
} 
situation. The deep rooted ethos of militarism is also another debacle leading to the stalemate. Unless the two countries repudiate the culture of the use of force and democratize their political environs as well as refrain from participating in the form of proxy wars and mutual interventions, the expectation of normalization will become a mirage.

\section{References}

[1] Abbink, Jon (1998). "Briefing: The Ethiopian and Eritrean Border Dispute", African Affairs, Vol. 97, No. 389, Pp. 551556.

[2] Abbink, Jon (2003a). "Ethiopia-Eritrea: Proxy Wars and Prospects of Peace in the Horn of Africa", Journal of Contemporary African Studies, Vol. 21, No. 3, Pp. 408-425.

[3] Abbink, Jon (2003b). "Badme and the Ethio- Eritrean Border: The Challenge of Demarcation in the Post War Period." Africa: Rivista trimestrale di studi e documentazione dell'Istituto italiano per l'Africae l'Oriente, Vol, 58, No. 2, Pp. 221-231.

[4] Ahmar, Moonis (1984). "The Eritrean Struggle for Emancipation", Pakistan Horizon, Vol. 37, No. 3, Pp. 49-64.

[5] Bahru Zewde (2006). "Eritrea and Ethiopia: In quest of a culture of peace and dialogue", in Leenco Lata (ed.), The Search for Peace: the Conflict between Ethiopia and Eritrea, proceedings of the scholarly conference on Ethiopia - Eritrea conflict, Oslo, Norway 6-7 July 2006.

[6] Bereketeab, Redie (2010) "The Complex Roots of the Second Eritrea- Ethiopia War: Re-examining the Causes", African Journal of International Affairs, Vol. 13, No. 1/2, Pp. 15-59.

[7] Berhane Woldegabriel (2006). "Eritrea: A War for National Unity", in Leenco Lata (ed.), The Search for Peace: the Conflict between Ethiopia and Eritrea, proceedings of the scholarly conference on Ethiopia - Eritrea conflict, Oslo, Norway 6-7 July 2006.

[8] Ciampi, Gabriele (2001). "Cartographic Problems of the Eritrea-Ethiopian Border", Africa LVI, Vol. 56, No. 2, Pp. 155189.

[9] Dima Noggo Sarbo (2006). "Ethiopia and Eritrea: ShortSighted Solution, Long Term Problems", in Leenco Lata (ed.), The Search for Peace: the Conflict between Ethiopia and Eritrea, proceedings of the scholarly conference on EthiopiaEritrea conflict, Oslo, Norway 6-7 July 2006.

[10] Gebru Asrat (2006) "Towards a Sustainable Peace between Ethiopia and Eritrea", in Leenco Lata (ed.), The Search for Peace: the Conflict between Ethiopia and Eritrea, proceedings of the scholarly conference on Ethiopia - Eritrea conflict, Oslo, Norway 6-7 July 2006.

[11] Gilkes, Patrick (1999). "Ethiopia -Perspectives of Conflict 1991-1999", Switzerland: Swiss Peace Foundation.

[12] Healy, Sally (2007). "Eritrea's Economic Survival: Summary record of a conference held on 20 April 2007", London: the Royal Institute of International Affairs.

[13] Healy, Sally and Plaut, Martin (2007). "Ethiopia and Eritrea: Allergic to Persuasion", Briefing paper, London: The Royal Institute of International Affairs.
[14] International Crisis Group -ICG (2003). "Ethiopia and Eritrea: War or Peace?", Africa Report, No. 68.

[15] International Crisis Group-ICG (2005). "Ethiopia and Eritrea: Preventing War", Africa Report, No.101.

[16] International Crisis Group-ICG (2010). "Eritrea: The Siege State", Africa Report, No.163.

[17] Kalewongel Minale (2008). "Ethiopia and Eritrea: the Quest for Peace and Normalizations", Unpublished MA Thesis, University of Tromsø, Norway.

[18] Kassahun Berhanu (2010). "The Ethiopian Transition in Regional Perspective: Election processes, Liberation movements and Democratic change in Africa", Conference Paper presented at Maputo, 8-11 April 2010.

[19] Kidane Mengisteab (2011). "Critical Factors in the Horn of Africa's Raging Conflicts", Discussion Paper, Uppsala: Nordiska Afrikainstitutet.

[20] Kidist Mulugeta (2011). "The Ethiopian-Eritrean War of 1998-2000: An Analysis of its Causes, Course, Impacts and Prospects", in Roba Sharamo and Berouk Mesfin (eds.), Regional Security in the post-Cold War Horn of Africa, Institute for Security Studies.

[21] Leenco Lata (2006). "Introduction", in Leenco Lata (ed.), The Search for Peace: the Conflict between Ethiopia and Eritrea, proceedings of the scholarly conference on Ethiopia - Eritrea conflict, Oslo, Norway 6-7 July 2006.

[22] Lobban, Richard (1976). "The Eritrean War: Issues and Implications", Canadian Journal of African Studies, Vol.10, No. 2, Pp. 335-346.

[23] Medhane Tadesse (1999). The Eritrean-Ethiopian War: Retrospect and Prospect; Addis Ababa: Mega printing press.

[24] Merera Gudina (2007). "Party Politics, Political Polarization and the Future of Ethiopian Democracy", Western Michigan University.

[25] Ogbazghi, Petros B. (2011). "Personal Rule in Africa: The Case of Eritrea", African Studies Quarterly, Volume 12, Issue 2.

[26] Plaut, Martin (2005/2006); "Ethiopia and Eritrea: Returning to War?", International Journal of Ethiopian Studies, Vol. 2, No. 1/2, Pp. 179-194. Pp. 15-59.

[27] Solomon Ayele D. (2004). "Ethiopian-Eritrean Relations: Reading the Balance Sheet", Situation Report, Institute for Security Studies (ISS).

[28] Tekeste Negash and Tronvoll, Kjetil (2000). Brothers at War: Making Sense of the Eritrea - Ethiopian War, Oxford: James Currey.

[29] Wondwosen Teshome (2009). "Ethiopian Opposition Political Parties and Rebel Fronts: Past and Present", International Journal of Human and Social Sciences, Vol. 4, No.1, Pp.60-68.

[30] Young, John (1996). "The Tigray and the Eritrean People's Liberation Fronts: a History of Tensions and Pragmatism", The Journal of Modern African Studies, 34(1), Pp. 105-120.

[31] Young, John_(1997). Peasant Revolution in Ethiopia: The Tigray People's Liberation Front, Cambridge: Cambridge University Press. 